\title{
Thyroxine Binding Globulin Protein Measurement
}

National Cancer Institute

\section{Source}

National Cancer Institute. Thyroxine Binding Globulin Protein Measurement. NCI

Thesaurus. Code C74746.

The determination of the amount of thyroxine binding globulin protein present in a sample. 